\title{
David Oliver: Health policy advice in the new number 10
}

\section{David Oliver consultant in geriatrics and acute general medicine}

Berkshire

Just before taking up his post in Boris Johnson's new support team, health policy adviser William Warr made quite a splash in a Daily Telegraph column. ${ }^{12}$

Generally, special health advisers in number 10 or Whitehall fly under the radar. Few people outside the healthcare policy and communications bubble would know their names or hear what they think. But in that column, Warr set out his views for public consumption.

Early reports on the new administration indicate that it is being run with control and strategic focus. Although Warr was not yet in post, I can't believe he was just sounding off. This was surely a tactical decision to get some ideas into the public domain, while keeping the new prime minister's hands clean.

So what did Warr say? Here are some worrying lowlights.

He told us that more money was not the solution to the NHS's problems, that the service was "hopelessly ill equipped" (to deal with chronic diseases) and a "highly centralized" "monolith," and that attempts to introduce new technology had been "feeble."

He attacked "traditional public health policies" as treating "everyone the same, regardless of lifestyle or risk" and criticised measures like food or drink levies as "sin taxes." "The only way to prevent is to predict," he said. This reinforced health secretary Matt Hancock's push for widespread genomic testing to identify people at high risk of diseases and annual health checks focusing on individual choice. ${ }^{34}$

Despite the lack of established evidence to show that genomic testing or digital solutions can drive improvements in population health, quality of care, or service efficiency, Warr is pushing a magical thinking narrative based on future potential, above better evidenced, but less shiny, solutions. If you want to predict early onset of diseases and premature death, for example, postcodes are a better bet than genes.

His comments fly in the face of expert evidence in public health around the effects of socioeconomic inequalities, pricing policy, and environments on health..$^{5-7}$ They ignore the impact of sustained attacks on public health funding or drug and alcohol services. ${ }^{89}$ They also reinforce a narrative that blames citizens for personal lifestyle choices and advocates less state interference.

As for the NHS's structures, the service has, since its inception, undergone continuous evolution and sporadic reform to adapt to new circumstances and policy fads. Big destabilising reforms have rarely delivered. We need to learn from history. There is no "clean slate" as we need to keep current services on the road. ${ }^{10}$

Current configuration and re-disorganisation of the NHS has been overseen by Johnson's own party since 2010, despite Warr claiming that the NHS had been "brainwashed by the financial targets introduced under Blair." This includes "any qualified provider" legislation, devolution of service leadership, and now workforce planning into 45 local integrated care systems. ${ }^{11}{ }^{12}$

Despite the prime minister's warm words and gestures towards the NHS, the agenda set out by his adviser and by the health secretary is clear: smaller state and more responsibility for individuals. This agenda deliberately bypasses inconvenient evidence and credible expertise wherever it conflicts with the neoliberal narrative, upsets industries with vested interests, or requires more government intervention in social policy. All this is coupled with an evangelical deification of digital and genomic technologies, destined to benefit their manufacturers.

As for becoming less "centralized" and less "monolithic," this looks like a precursor to more private insurers and providers taking over parts of a service whose ethos and model are being talked down and undermined.

Competing interests: See www.bmj.com/about-bmj/freelance-contributors. Provenance and peer review: Commissioned; not externally peer reviewed

1 Warr W. Will our next PM be bold enough to tackle the biggest challenge facing the NHS? Telegraph 19 Jul 2019. https://www.telegraph.co.uk/politics/2019/07/19/will-next-pm-boldenough-tackle-biggest-challenge-facing-nhs/

McLellan A. PM's new health adviser says "ill-equipped" NHS does not need "more money." HSJ 16 Aug 2019. https://www.hsj.co.uk/news/pms-new-health-adviser-says-ill-equippednhs-does-not-need-more-money/7025770.article

3 Department of Health and Social Care. Matt Hancock launches tech vision to build the most advanced health and care system in the world. 17 Oct 2018. https://www.gov.uk/ government/news/matt-hancock-launches-tech-vision-to-build-the-most-advanced-healthand-care-system-in-the-world 
4 Crouch $\mathrm{H}$. Hancock says the "tide of technology should be embraced." Digital Health 19 Mar 2019. https://www.digitalhealth.net/2019/03/hancock-says-the-tide-of-technologyshould-be-embraced/

5 The Health Foundation. Health equity in England: the Marmot Review 10 years on. 8 Oct 2018. https://www.health.org.uk/news-and-comment/news/health-equity-in-england-themarmot-review-10-years-on?

gclid=Cj0KCQjwwIPrBRCJARIsAFIVT8905UXZyMRvgssGB1QAnNvIrWn8wngE1GkmboskGRm2fZhOhZo7OlaAuHQEALw wcB

6 Mikkelsen B, Williams J, Rakovac I, etal . Life course approach to prevention and control of non-communicable diseases. BMJ 2019;364:I257. 10.1136/bmj.I257 30692103

7 Williams R. [electronic response to Oliver D. David Oliver: Government's approach to alcohol harm is incoherent]. BMJ 2018. https://www.bmj.com/content/362/bmj.k3836/ rapid-responses

8 The Health Foundation. Additional £3.2bn a year needed to reverse impact of government cuts to public health services. 24 Oct 2018. https://www.health.org.uk/news-and-comment/ news/additional-£32bn-a-year-needed-to-reverse-impact-of-government-cuts-to-publichelath?gclid=Cj0KCQjwwIPrBRCJARISAFIVT8-hhkjPtPD

UrBTolZuv63rOxsxtk2O5bu7pVVK4gV4goOtlbpVrsaAp8LEALw wcB

9 Rhodes D. Drug and alcohol services cut by $£ 162 \mathrm{~m}$ as deaths increase. BBC 11 May 2018. https://www.bbc.co.uk/news/uk-england-44039996

10 Nuffield Trust. Doomed to repeat? Lessons from the history of NHS reform. 16 Oct 2018 https://www.nuffieldtrust.org.uk/comment-series/doomed-to-repeat-it

11 King's Fund. Never Again? The story of the Health and Social Care Act 2012. 12 Jul 2012. https://www.kingsfund.org.uk/publications/never-again

12 King's Fund. Alternative guides to health care. https://www.kingsfund.org.uk/projects/ alternative-guides-health-care

Published by the BMJ Publishing Group Limited. For permission to use (where not already granted under a licence) please go to http://group.bmj.com/group/rights-licensing/ permissions 